\title{
A Novel Hemagglutinin with Antiproliferative Activity against Tumor Cells from the Hallucinogenic Mushroom Boletus speciosus
}

\author{
Jian Sun, ${ }^{1,2}$ Tzi-Bun $\mathrm{Ng}^{3}{ }^{\text {Hexiang Wang, }}{ }^{2}$ and Guoqing Zhang ${ }^{1}$ \\ ${ }^{1}$ Key Laboratory of Urban Agriculture (North) of Ministry of Agriculture, College of Biological Sciences and Engineering, Beijing \\ University of Agriculture, Beijing 102206, China \\ ${ }^{2}$ State Key Laboratory for Agrobiotechnology and Department of Microbiology, China Agricultural University, Beijing 100193, China \\ ${ }^{3}$ School of Biomedical Sciences, Faculty of Medicine, The Chinese University of Hong Kong, Shatin, New Territories, Hong Kong
}

Correspondence should be addressed to Hexiang Wang; hxwang@cau.edu.cn and Guoqing Zhang; zhanggq1001@gmail.com

Received 28 January 2014; Revised 30 March 2014; Accepted 29 April 2014; Published 29 May 2014

Academic Editor: Marcelo A. Soares

Copyright (C) 2014 Jian Sun et al. This is an open access article distributed under the Creative Commons Attribution License, which permits unrestricted use, distribution, and reproduction in any medium, provided the original work is properly cited.

\begin{abstract}
Little was known about bioactive compounds from the hallucinogenic mushroom Boletus speciosus. In the present study, a hemagglutinin (BSH, B. speciosus hemagglutinin) was isolated from its fruiting bodies and enzymatic properties were also tested. The chromatographic procedure utilized comprised anion exchange chromatography on Q-Sepharose, cation exchange chromatography on CM-Cellulose, cation exchange chromatography on SP-Sepharose, and gel filtration by FPLC on Superdex 75. The hemagglutinin was a homodimer which was estimated to be approximately $31 \mathrm{kDa}$ in size. The activity of BSH was stable up to $60^{\circ} \mathrm{C}$, while there was a precipitous drop in activity when the temperature was elevated to $70^{\circ} \mathrm{C}$. $\mathrm{BSH}$ retained $25 \%$ hemagglutinating activity when exposed to $100 \mathrm{mM} \mathrm{NaOH}$ and $25 \mathrm{mM} \mathrm{HCl}$. The activity was potently inhibited by $1.25 \mathrm{mM} \mathrm{Hg}^{2+}$ and slightly inhibited by $\mathrm{Fe}^{2+}, \mathrm{Ca}^{2+}$, and $\mathrm{Pb}^{2+}$. None of the sugars tested showed inhibition towards $\mathrm{BSH}$. Its hemagglutinating activity towards human erythrocytes type $\mathrm{A}$, type $\mathrm{B}$, and type $\mathrm{AB}$ was higher than type $\mathrm{O}$. The hemagglutinin showed antiproliferative activity towards hepatoma Hep G2 cells and mouse lymphocytic leukemia cells (L1210) in vitro, with $\mathrm{IC}_{50}$ of $4.7 \mu \mathrm{M}$ and $7.0 \mu \mathrm{M}$, respectively. It also exhibited HIV-1 reverse transcriptase inhibitory activity with an $\mathrm{IC}_{50}$ of $7.1 \mu \mathrm{M}$.
\end{abstract}

\section{Introduction}

Lectins and hemagglutinins are nonimmune proteins or glycoproteins that exhibit specific binding to carbohydrates on the cell surface. They can agglutinate cells through sugarspecific binding sites for polysaccharides and glycoconjugates [1]. Lectins were first identified in plants and are now known to be distributed widely throughout the nature, including plants, animals, fungi, bacteria, and viruses [2]. In plants, they are mainly storage proteins and serve in defence against insects or fungi [3]. Lectins or hemagglutinins are important receptors in animals, such as human C-type lectin langerin [4] and rat liver asialoglycoprotein receptor [5]. In mushrooms, lectins play a pivotal role in dormancy, growth, morphogenesis, morphological changes consequent on parasitic infections, and molecular recognition during the early stages of mycorrhization [3].

Mushrooms of the Boletus genus have been known since ancient times for their delicious taste as edible wild food. However, some of them are toxic. There are only several reports about bioactive substance such as lectins $[6,7]$, ribonucleases [8], and toxic proteins [9] from this genus. Boletus speciosus is a rare wild hallucinogenic mushroom and can cause "lilliputian hallucination" when cooked in a wrong way or eaten too much. The stipe of the mushroom is yellow and becomes blue quickly after bruise. That is why locals of Southwest China call the mushroom "Jian Shou Qing" which means the mushroom changes to blue when touched. The toxicity of the mushroom is neuropsychiatric, and the patient can see little joyous creatures jumping and 
dancing around. The toxin was defined as hallucinogens but not isolated up to now [10]. On the other hand, the mushroom is considered as a delicious mushroom by local people since the poisoning symptoms vanished after being boiled up.

There is dearth information pertaining to bioactive substances of $B$. speciosus. The present investigation aimed to isolate and characterize a hemagglutinin from the fruiting body of $B$. speciosus and compare its characteristics with other known lectins or hemagglutinins from Boletus genus such as Boletus edulis lectin [11].

\section{Materials and Methods}

2.1. Isolation of Hemagglutinin. Ion exchange chromatography of dried B. speciosus fruiting bodies ( $20 \mathrm{~g})$ was carried out using a $10 \times 100 \mathrm{~cm}$ column of Q-Sepharose (GE Healthcare). The extract was first homogenized in $0.15 \mathrm{M} \mathrm{NaCl}(10 \mathrm{~mL}$ per gram) and extracted overnight at $4^{\circ} \mathrm{C}$. Then the homogenate was centrifuged at $12,000 \mathrm{rpm}$ for 30 minutes at $4^{\circ} \mathrm{C}$. The supernatant was collected and $\left(\mathrm{NH}_{4}\right)_{2} \mathrm{SO}_{4}$ was added to the supernatant until $80 \%$ saturation is reached. The mixture was left at $4^{\circ} \mathrm{C}$ for 8 hours before centrifugation at 10,000 rpm for $25 \mathrm{~min}$. The precipitate was redissolved and dialyzed to remove $\left(\mathrm{NH}_{4}\right)_{2} \mathrm{SO}_{4}$ before applying to a Q-Sepharose column in $10 \mathrm{mM}$ Tris-HCl buffer ( $\mathrm{pH} \mathrm{8.0).} \mathrm{After} \mathrm{removal} \mathrm{of} \mathrm{the}$ unadsorbed fraction Q1, adsorbed proteins were desorbed stepwise with $50 \mathrm{mM} \mathrm{NaCl}$ in the Tris- $\mathrm{HCl}$ buffer to yield fraction Q2 and then with $300 \mathrm{mM}$ and $1 \mathrm{M} \mathrm{NaCl}$ in the Tris$\mathrm{HCl}$ buffer to yield fractions Q3 and Q4. Fraction Q3 with hemagglutinating activity was then subjected to ion exchange chromatography on a $2.5 \times 30 \mathrm{~cm}$ column of CM-Cellulose (Sigma) in $10 \mathrm{mM}$ sodium acetate-acetic acid buffer (NaAc$\mathrm{HAc}, \mathrm{pH}$ 5.2). After removal of the unadsorbed fraction $\mathrm{C} 1$ with the same buffer, adsorbed proteins were eluted with $150 \mathrm{mM} \mathrm{NaCl}$ in the NaAc-HAc buffer to yield fraction $\mathrm{C} 2$ and then with $300 \mathrm{mM}$ and $1 \mathrm{M} \mathrm{NaCl}$ in the $\mathrm{NaAc}$ HAc buffer to yield fractions C3 and C4. Fraction C3 with hemagglutinating activity was then subjected to ion exchange chromatography on a $1.0 \times 10 \mathrm{~cm}$ column of SP-Sepharose (GE Healthcare) in $10 \mathrm{mM} \mathrm{NaAc-HAc}$ buffer ( $\mathrm{pH}$ 5.2). After removal of the unadsorbed fraction $\mathrm{S} 1$ with the same buffer, adsorbed proteins were eluted with a linear $0-0.5 \mathrm{M} \mathrm{NaCl}$ gradient in the NaAc-HAc buffer. The adsorbed fraction S3 was further purified by gel filtration on a fast protein liquid chromatography Superdex 75 10/300 GL column (GE Healthcare).

2.2. Determination of Molecular Weight and N-Terminal Sequence. The molecular weight of the active fraction (SU1) was subsequently determined by sodium dodecyl sulfatepolyacrylamide gel electrophoresis (SDS-PAGE) in accordance with the procedure of Laemmli and Favre [12]. Molecular weight determination was also performed by using FPLC-gel filtration as described above. N-terminal sequence determination of the protein was carried out using an HP G-1000A Edman degradation unit and an HP 1000 HPLC system [13].
2.3. Assay for Hemagglutinating Activity. A serial twofold dilution of the hemagglutinin solution in microtiter U-plates $(25 \mu \mathrm{L})$ was mixed with $25 \mu \mathrm{L}$ of a $2 \%$ suspension of rabbit red erythrocytes in phosphate-buffered saline $(\mathrm{pH}$ 7.2) at room temperature. The results were recorded after approximately half an hour when full sedimentation was observed in the blank. The hemagglutination titer, defined as the reciprocal of the highest dilution exhibiting hemagglutination, was regarded as one hemagglutination unit. Specific activity is the number of hemagglutination units/mg protein [2]. All determinations were performed in triplicate.

The hemagglutinating inhibition tests to investigate the inhibitory activities of various carbohydrates towards the hemagglutinin were performed in a manner analogous to the hemagglutination test. Serial twofold dilutions of sugar samples (200 $\mathrm{mM}$ to $0.195 \mathrm{mM}$ ) were prepared in phosphatebuffered saline. All of the dilutions were mixed with an equal volume $(25 \mu \mathrm{L})$ of a solution of the hemagglutinin with 32 hemagglutination units. The mixture was allowed to stand for 30 minutes at room temperature and then mixed with $50 \mu \mathrm{L}$ of a $2 \%$ rabbit erythrocyte suspension. The minimum concentration of the sugar in the final reaction mixture, which completely inhibited 32 hemagglutination units of the protein preparation, was calculated. The sugars tested included inositol, D-melibiose, D(-)fructose, $\mathrm{L}(+)$-rhamnose, sorbose, $\mathrm{D}(+)$-galactose, $\mathrm{D}(+)$ mannose, $\alpha$-lactose, $\mathrm{D}(+)$-xylose, $\mathrm{L}(+)$-arabinose, $\mathrm{D}$-glucose, maltose, raffinose, cellobiose, inulin, p-nitrophenyl- $\alpha$-Dglucopyranoside, $\mathrm{p}$-nitrophenyl- $\beta$-D-glucopyranoside, and inositol.

The effects of temperature, $\mathrm{NaOH}$ solution, $\mathrm{HCl}$ solution, and solutions of metallic chlorides (including those of $\mathrm{Fe}^{2+}$, $\mathrm{K}^{+}, \mathrm{Ca}^{2+}, \mathrm{Cd}^{2+}, \mathrm{Cu}^{2+}, \mathrm{Hg}^{2+}, \mathrm{Mg}^{2+}, \mathrm{Mn}^{2+}, \mathrm{Pb}^{2+}, \mathrm{Zn}^{2+}, \mathrm{Al}^{3+}$, and $\mathrm{Fe}^{3+}$ ) on hemagglutinating activity of the protein were examined as previously described [2].

2.4. Assay of Antiproliferative Activity on Tumor Cell Lines. The tumor cell lines Hep G2 (hepatoma) and L1210 (leukemia) were purchased from American Type Culture Collection (ATCC). The cell lines were maintained in Dulbecco modified Eagle's medium (DMEM) supplemented with $10 \%$ fetal bovine serum (FBS), $100 \mathrm{mg} / \mathrm{L}$ streptomycin, and $100 \mathrm{IU} / \mathrm{mL}$ penicillin at $37^{\circ} \mathrm{C}$ in a humidified atmosphere of $5 \% \mathrm{CO}_{2}$. Cells $\left(1 \times 10^{4}\right)$ in their exponential growth phase were seeded into each well of a 96-well culture plate (Nunc, Denmark) and incubated for 3 hours before addition of the hemagglutinin. Incubation was carried out for another 48 hours. Radioactive precursor, $1 \mu \mathrm{Ci}$, ([ ${ }^{3} \mathrm{H}$-methyl] thymidine, from GE Healthcare) was then added to each well and incubated for 6 hours. The cultures were then harvested by using a cell harvester. The incorporated radioactivity was determined by liquid scintillation counting [14].

2.5. Assay for HIV-1 Reverse Transcriptase (HIV-1 RT) Inhibitory Activity. The assay for HIV-1 RT inhibitory activity was assessed by using an enzyme-linked immunosorbent assay (ELISA) kit from Boehringer Mannheim (Germany). 
TABLE 1: Yields and specific hemagglutinating activities of various chromatographic fractions at different stages of B. speciosus hemagglutinin (BSH) purification.

\begin{tabular}{lccccc}
\hline Fraction & Yield $(\mathrm{mg})$ & Specific activity $(\mathrm{U} / \mathrm{mg})$ & Total activity $(\mathrm{U})$ & Recovery of activity $(\%)$ & Folds of purification \\
\hline Extract & 1496.6 & 5.3 & 7904.0 & 100.0 & 1.0 \\
Q3 & 176.4 & 30.4 & 5299.2 & 67.0 & 5.7 \\
C3 & 35.9 & 88.7 & 3187.2 & 40.3 & 16.8 \\
S3 & 10.5 & 193.0 & 2035.2 & 25.8 & 36.6 \\
SU1 & 5.7 & 220.2 & 1255.1 & 15.9 & 41.7 \\
\hline
\end{tabular}

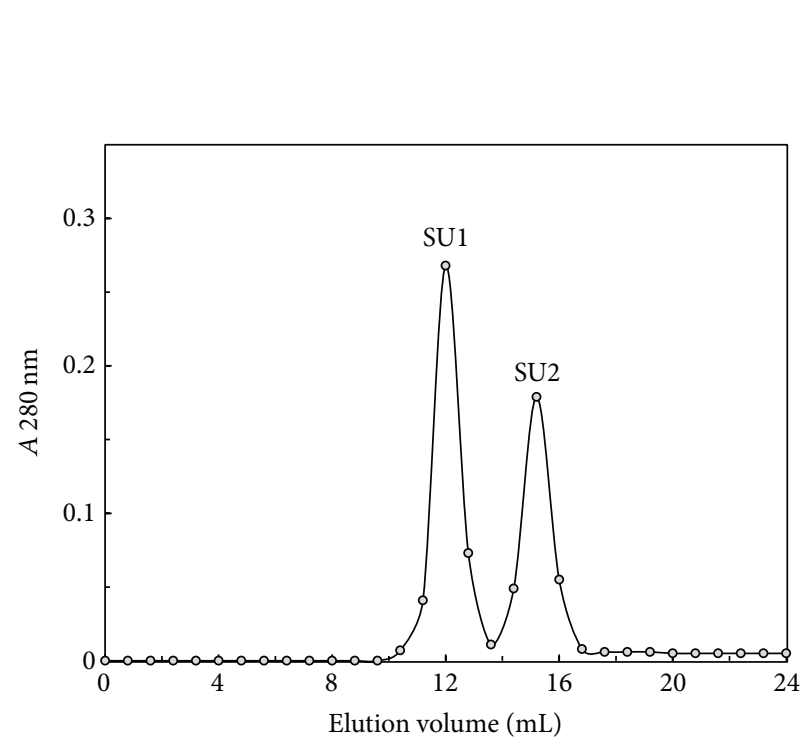

(a)

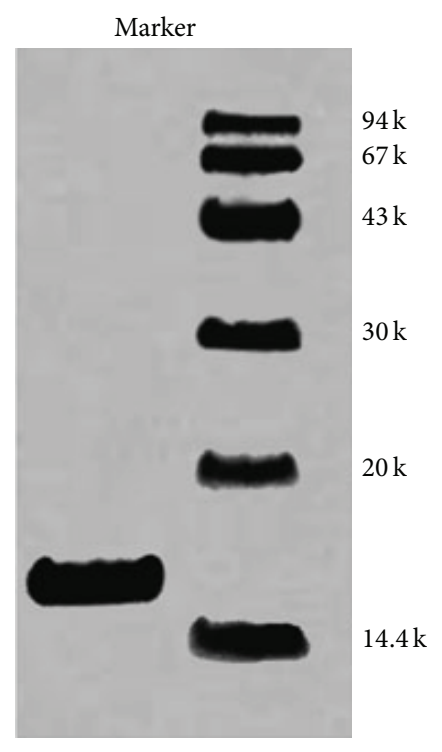

(b)

FIGURE 1: (a) Gel filtration of fraction on Superdex 75 HR 10/30 column by FPLC. Fraction SU1 represents purified hemagglutinin BSH. (b) SDS-PAGE of purified BSH. Right lane: molecular weight markers, from top downwards, phosphorylase b ( $94 \mathrm{kDa})$, bovine serum albumin $(67 \mathrm{kDa})$, ovalbumin $(43 \mathrm{kDa})$, carbonic anhydrase $(30 \mathrm{kDa})$, soybean trypsin inhibitor $(20 \mathrm{kDa})$, and lactalbumin $(14.4 \mathrm{kDa})$.

The assay takes advantage of the ability of reverse transcriptase to synthesize DNA, starting from the template/primer hybrid poly(A) oligo(dT) 15 . The digoxigenin- and biotinlabeled nucleotides in an optimized ratio are incorporated into one of the same DNA molecules, which is freshly synthesized by the RT. The detection and quantification of synthesized DNA as a parameter for RT activity follow sandwich ELISA protocol. Biotin-labeled DNA binds to the surface of microtiter plate modules that have been precoated with streptavidin. An antibody to digoxigenin, conjugated to peroxidase (anti-DIG-POD), subsequently binds to the digoxigenin-labeled DNA. Finally, the peroxidase substrate is added. The peroxidase enzymes catalyze the cleavage of the substrate and produce a colored reaction product. The adsorbance of the samples at $405 \mathrm{~nm}$ can be determined by using a microtiter plate (ELISA) reader and is directly correlated to the level of RT activity. A fixed amount (4$6 \mathrm{ng}$ ) of recombinant HIV-1 RT was used. The inhibitory activity of the hemagglutinin was calculated as percentage inhibition as compared to a control without the protein [14].
2.6. Assay for Antifungal Activity. The assay for antifungal activity towards the phytopathogenic fungi Fusarium oxysporum, Rhizoctonia cerealis, Rhizoctonia solani, and Sclerotinia sclerotiorum was carried out in $100 \times 15 \mathrm{~mm}$ petri dishes containing $10 \mathrm{~mL}$ of potato dextrose agar (PDA). After the mycelial colony had developed, sterile blank paper disks $(0.625 \mathrm{~cm}$ in diameter) were placed at a distance of $0.5 \mathrm{~cm}$ away from the rim of the mycelial colony. An aliquot $(15 \mu \mathrm{L})$ of the hemagglutinin was added to a disk. The dishes were incubated at $23^{\circ} \mathrm{C}$ for 72 hours until mycelial growth had enveloped the disks containing the control and had formed crescents of inhibition around disks containing samples with antifungal activity [13].

\section{Results}

3.1. Purification of BSH. The precipitate from ammonium sulfate precipitation was redissolved and dialyzed as crude protein extract. Then it was applied to an ion exchange chromatography Q-Sepharose column. One of the adsorbed fractions, fraction Q3, showed hemagglutinating activity 
TABLE 2: Hemagglutinating activity of BSH on rabbit and human erythrocytes.

\begin{tabular}{lccccc}
\hline & \multirow{2}{*}{ Rabbit erythrocytes } & \multicolumn{3}{c}{ Human erythrocytes } \\
& & $\mathrm{A}$ & $\mathrm{B}$ & $\mathrm{O}$ & $\mathrm{AB}$ \\
\hline Hemagglutinating activity (\%) & 100 & 50 & 50 & 25 & 50 \\
\hline
\end{tabular}

Note: initial hemagglutinating activity was $32 \mathrm{U}$.

TABLE 3: Effect of temperature and $\mathrm{pH}$ values on hemagglutinating activity of $\mathrm{BSH}$.

\begin{tabular}{|c|c|c|c|c|c|c|}
\hline Temperature $\left({ }^{\circ} \mathrm{C}\right)$ & 30 & 40 & 50 & 60 & 70 & 80 \\
\hline Residual hemagglutinating activity (\%) & 100 & 100 & 100 & 100 & 12.5 & 0 \\
\hline $\mathrm{pH}$ values & 2.2 & 1.9 & 1.6 & 1.3 & 1.0 & 0.7 \\
\hline Residual hemagglutinating activity (\%) & 100 & 50 & 25 & 0 & 0 & 0 \\
\hline $\mathrm{pH}$ values & 11.8 & 12.1 & 12.4 & 12.7 & 13.0 & 13.3 \\
\hline Residual hemagglutinating activity (\%) & 100 & 100 & 50 & 50 & 25 & 0 \\
\hline
\end{tabular}

Note: initial hemagglutinating activity was $32 \mathrm{U}$.

(Table 1). Subsequently, the active fraction Q3 was applied to CM-Cellulose and yielded an unadsorbed fraction $\mathrm{C} 1$ and three adsorbed fractions C2, C3, and C4. Hemagglutinating activity resided in fraction C3 (Table 1). Upon ion exchange chromatography on SP-Sepharose, fraction C3 was resolved into a large unadsorbed fraction $\mathrm{S} 1$ and two smaller adsorbed fractions (S2 and S3) of approximately the same size. Activity resided in fraction S3. Upon gel filtration on Superdex 75, S3 was resolved into a larger peak SU1 (with a molecular mass of $31 \mathrm{kDa}$ ) and a smaller peak SU2 (Figure 1(a)). Hemagglutinating activity was enriched in SU1 which appeared as a single band with a molecular mass of $15.5 \mathrm{kDa}$ in SDSPAGE (Figure 1(b)). About 40-fold purification was achieved (Table 1).

3.2. Biological Activities of BSH. The interactions of lectins or hemagglutinins with cells can, in many instances, be inhibited specifically by simple sugars. However, BSH showed no specificity towards the various carbohydrates tested, including inositol, O-nitrophenyl-b-D-galactopyranoside, L-sorbose, raffinose, L-rhamnose, D-fructose, D-mannose, cellobiose, L-arabinose, D-xylose, D-melibiose, lactose, inulin, maltose, $\mathrm{D}$-galactose, and D-glucose. It is suggested that the protein is a hemagglutinin but not a lectin. Its lower activities on human type $\mathrm{O}$ erythrocytes compared with type $\mathrm{A}$, type $\mathrm{B}$, and type $\mathrm{AB}$ indicate the binding is related to some ligand which has different distribution to blood types (Table 2).

The activity of BSH was stable up to $60^{\circ} \mathrm{C}$ followed by a precipitous decline from 64 to 8 hemagglutination units when the temperature was raised to $70^{\circ} \mathrm{C}$. At and above $80^{\circ} \mathrm{C}$ activity was undetectable (Table 3 ). The hemagglutinin was stable in $6 \mathrm{mM} \mathrm{HCl}(\mathrm{pH} 2.2)$ and $12.5 \mathrm{mM} \mathrm{NaOH}(\mathrm{pH}$ 12.1), while it was reduced by $75 \%$ in $25 \mathrm{mM} \mathrm{HCl}$ (pH 1.3) and $100 \mathrm{mM} \mathrm{NaOH}(\mathrm{pH} 13.0)$. The activity disappeared in $50 \mathrm{mM} \mathrm{HCl}$ (pH 1.9) and $200 \mathrm{mM} \mathrm{NaOH}$ (pH 13.3) (Table 3). The hemagglutinating activity was unaffected in the presence of $\mathrm{K}^{+}, \mathrm{Cd}^{2+}, \mathrm{Cu}^{2+}, \mathrm{Mg}^{2+}, \mathrm{Mn}^{2+}, \mathrm{Zn}^{2+}, \mathrm{Al}^{3+}$, and $\mathrm{Fe}^{3+}$ ions (1.25-10 mM) but was reduced by $\mathrm{Fe}^{2+}$ (5-10 mM), Ca ${ }^{2+}(5-$ $10 \mathrm{mM})$, and $\mathrm{Pb}^{2+}(2.5-10 \mathrm{mM})$ and potently reduced by $\mathrm{Hg}^{2+}$ (1.25-10 $\mathrm{mM})$ ions (Table 4).
TABLE 4: Effects of cations on hemagglutinating activity of BSH.

\begin{tabular}{lcccc}
\hline Cation $(\mathrm{mM})$ & 10 & 5 & 2.5 & 1.25 \\
\hline $\mathrm{Hg}^{2+}$ & 0 & 0 & 0 & 2 \\
$\mathrm{Fe}^{2+}$ & 8 & 16 & 32 & 32 \\
$\mathrm{Ca}^{2+}$ & 16 & 16 & 32 & 32 \\
$\mathrm{~Pb}^{2+}$ & 16 & 16 & 16 & 32 \\
$\mathrm{~K}^{+}$ & 32 & 32 & 32 & 32 \\
$\mathrm{Cd}^{2+}$ & 32 & 32 & 32 & 32 \\
$\mathrm{Cu}^{2+}$ & 32 & 32 & 32 & 32 \\
$\mathrm{Mg}^{2+}$ & 32 & 32 & 32 & 32 \\
$\mathrm{Mn}^{2+}$ & 32 & 32 & 32 & 32 \\
$\mathrm{Zn}^{2+}$ & 32 & 32 & 32 & 32 \\
$\mathrm{Al}^{3+}$ & 32 & 32 & 32 & 32 \\
$\mathrm{Fe}^{3+}$ & 32 & 32 & 32 & 32 \\
\hline
\end{tabular}

Note: initial hemagglutinating activity was $32 \mathrm{U}$.

BSH showed antiproliferative activity towards human hepatoma Hep G2 cells and mouse lymphocytic leukemia cells (L1210) with $\mathrm{IC}_{50}$ of $4.7 \mu \mathrm{M}$ and $7.0 \mu \mathrm{M}$, respectively (Figure 2). It exhibited HIV-1 reverse transcriptase inhibitory activity with an $\mathrm{IC}_{50}$ of $7.1 \mu \mathrm{M}$ (Figure 3 ). No inhibitory activity against the test with four phytopathogenic fungi was found when the hemagglutinin amount was up to $2.5 \mathrm{mg}$ (data not shown).

\section{Discussion}

Although mushroom species from genus Boletus are delicious (e.g., B. edulis), some of them are toxic or even deadly. $B$. magnificus and B. speciosus cause hallucinogenic toxins and $B$. erythropus and $B$. luridus manifest insecticidal activities, while $B$. satanas causes deadly liver damage, gastrointestinal upset, and hemolysis [10,15]. Very little is known about mushroom lectins or hemagglutinins from the genus Boletus, since they are rare in nature and cannot yet be artificially cultured. B. speciosus hemagglutinin $(\mathrm{BSH})$ is compared herein with a lectin from another Boletus species, B. edulis lectin [11] 
TABLE 5: Comparison of characteristics of BSH with B. edulis lectin.

\begin{tabular}{|c|c|c|}
\hline Characteristics & Boletus speciosus hemagglutinin & B. edulis lectin [11] \\
\hline \multicolumn{3}{|l|}{ Chromatographic behavior } \\
\hline DEAE ion exchanger & Unadsorbed & Unadsorbed \\
\hline Q ion exchanger & Adsorbed & NA \\
\hline SP ion exchanger & Adsorbed & NA \\
\hline $\mathrm{CM}$ ion exchanger & Adsorbed & Adsorbed \\
\hline Molecular mass (kDa) & 31 & 32.6 \\
\hline Subunit molecular mass $(\mathrm{kDa})$ & 15.5 & 16.3 \\
\hline $\mathrm{N}$-terminal amino acid sequence & ANVKIVK & TYGIALRV \\
\hline Thermostability & $60^{\circ} \mathrm{C}$ & $60^{\circ} \mathrm{C}$ \\
\hline pH stability & $<12.5 \mathrm{mM} \mathrm{NaOH} ;<6.25 \mathrm{mM} \mathrm{HCl}$ & $<25 \mathrm{mM} \mathrm{NaOH} ;<25 \mathrm{mM} \mathrm{HCl}$ \\
\hline Sugar specificity & Unknown & Xylose, melibiose \\
\hline $\begin{array}{l}\text { Effect of cations on } \\
\text { hemagglutinating activity }\end{array}$ & $\begin{array}{l}\text { Inhibited by } \mathrm{Hg}^{2+}, \mathrm{Fe}^{2+}, \mathrm{Ca}^{2+}, \\
\text { and } \mathrm{Pb}^{2+i} \text { ions; no augmentation } \\
\text { observed }\end{array}$ & $\begin{array}{l}\text { inhibited by } \mathrm{Mg}^{2+}, \mathrm{Mn}^{2+} \text {, and } \\
\mathrm{Zn}^{2+} \text { ions; augmented by } \mathrm{Fe}^{3+} \\
\text { and } \mathrm{Al}^{3+} \text { ions }\end{array}$ \\
\hline Antifungal activity & Undetectable & Undetectable \\
\hline Antiproliferative activity & $\mathrm{IC}_{50}$ of $4.7-7.0 \mu \mathrm{M}$ & NA \\
\hline HIV-1 RT inhibitory activity & $\mathrm{IC}_{50}$ of $7.1 \mu \mathrm{M}$ & $\mathrm{IC}_{50}$ of $14.3 \mu \mathrm{M}$ \\
\hline
\end{tabular}

NA: not available.

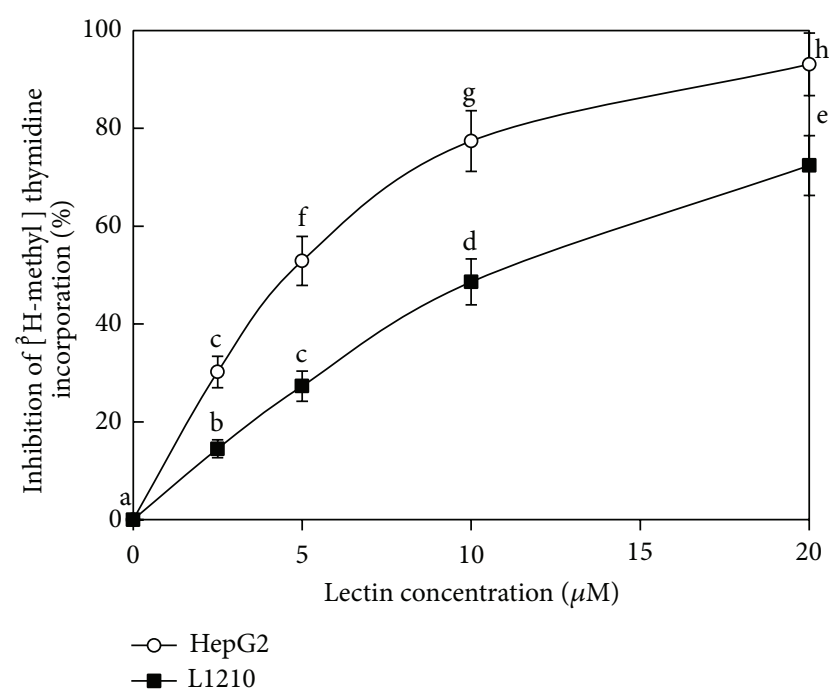

FIgURE 2: Antiproliferative activities of BSH towards Hep G2 and L1210 cell lines in vitro. The $\mathrm{IC}_{50}$ values towards Hep G2 and L1210 cells were $4.7 \mu \mathrm{M}$ and $7.0 \mu \mathrm{M}$, respectively. Each value in both panels represents the means $\pm \mathrm{SD}(n=3)$. Different letters $(\mathrm{a}, \mathrm{b}, \mathrm{c}, \ldots)$ next to the data points indicate statistically significant differences $(P<$ 0.05 ) when the data were analyzed by analysis of variance followed by Duncan's multiple range tests.

(Table 5). The two blood cell hemagglutinating proteins share similar chromatographic behavior on cationic and anionic exchangers; both are adsorbed on CM-Cellulose and unadsorbed on DEAE-Cellulose. They are distinct from some other mushroom lectins which are adsorbed on both chromatographic media $[16,17]$. Their molecular mass is around $32 \mathrm{kDa}$. They are both dimeric, which is in line with reports on

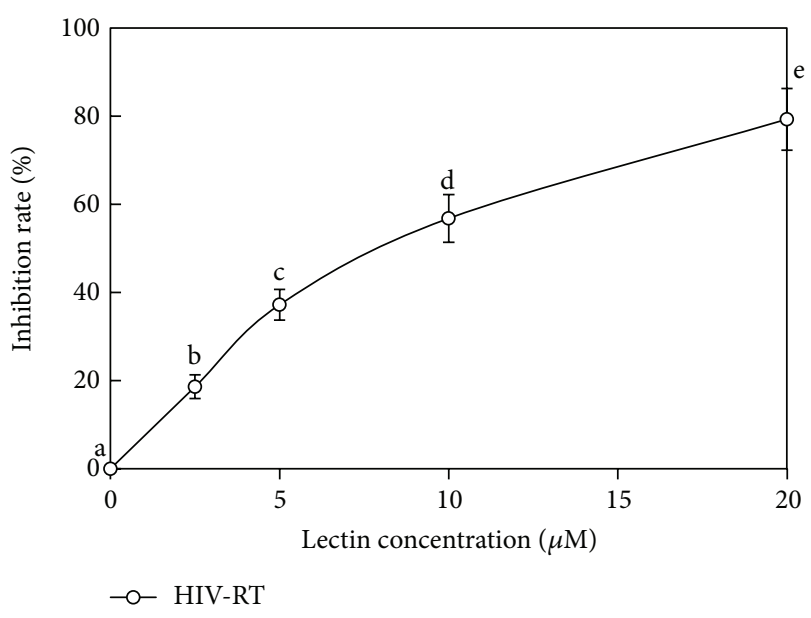

FIGURE 3: Inhibitory activity of BSH towards HIV-1 reverse transcriptase. It exhibited HIV-1 RT inhibitory activity with an $\mathrm{IC}_{50}$ of $7.1 \mu \mathrm{M}$. Each value in both panels represents the means $\pm \mathrm{SD}$ $(n=3)$. Different letters $(a, b, c, \ldots)$ next to the data points indicate statistically significant differences $(P<0.05)$ when the data were analyzed by analysis of variance followed by Duncan's multiple range tests.

dimeric lectins from Agaricus edulis [18], Volvariella volvacea [19], Xerocomus spadiceus [20], and Lactarius flavidulus [17]. Regarding thermostability, they can withstand temperatures no higher than $60^{\circ} \mathrm{C}$. Nevertheless, they are more thermostable than lectins from some other mushrooms, like Pleurotus ostreatus [21], Schizophyllum commune [22], and L. flavidulus [17], which are unstable above $40^{\circ} \mathrm{C}$. None of these mushroom lectins showed antifungal activity. However, BSH showed a lower $\mathrm{pH}$ stability and a higher HIV-1 RT inhibitory 
activity $\left(\mathrm{IC}_{50}\right.$ was $7.1 \mu \mathrm{M}$ compared with $14.3 \mu \mathrm{M}$ for B. edulis lectin). The two Boletus hemagglutinating proteins demonstrate different sugar specificities. $B$. edulis lectin exhibited a unique sugar specificity towards xylose and melibiose, while BSH showed no specificity towards the variety of sugars tested. There are reports about lectins inhibited by fetuin and glycoprotein rather than simple saccharides [23]. The effects of various cations on the two proteins are also different. $\mathrm{Fe}^{3+}$ and $\mathrm{Al}^{3+}$ ions augmented the hemagglutinating activity of $B$. edulis lectin but none of the ions tested enhanced the hemagglutinating activity; $\mathrm{Hg}^{2+}$ ions potently inhibited the hemagglutinating activity of BSH but did not affect $B$. edulis lectin. Besides, the N-terminal sequence of BSH (ANVKIVK) exhibited no homology to B. edulis lectin (TYGIALRV) or any other purified fungal lectins.

Most of fungal lectins manifest antiproliferative activity against tumor cell lines. BSH is characterized by an ability to inhibit proliferation of two tumor cell lines, human hepatoma Hep G2 cells and mouse lymphocytic leukemia cells (L1210) with $\mathrm{IC}_{50}$ of $4.7 \mu \mathrm{M}$ and $7.0 \mu \mathrm{M}$, respectively. Lectins from some other mushrooms, such as Agaricus bisporus (25 $\mu \mathrm{g} / \mathrm{mL}$ towards MCF-7 cells) [24], Tricholoma mongolicum ( $40 \mu \mathrm{g} / \mathrm{mL}$ towards PU5-1.8 cells) [25], V. volvacea [19], Pholiota adiposa $(2.1 \mu \mathrm{M}$ towards Hep G2 cells and 3.2 $\mu \mathrm{M}$ towards MCF-7 cells) [26], P. ostreatus [21], Russula lepida $(1.6 \mu \mathrm{M}$ towards Hep G2 cells and $0.9 \mu \mathrm{M}$ towards MCF-7 cells) [2], L. flavidulus $(8.90 \mu \mathrm{M}$ towards Hep G2 cells and $6.81 \mu \mathrm{M}$ towards L1210 cells) [17], and Hericium erinaceus $(56.1 \mu \mathrm{M}$ towards Hep G2 cells and $76.5 \mu \mathrm{M}$ towards MCF-7 cells) [27], also manifested this activity. The potent antiproliferative activity of $\mathrm{BSH}$ is remarkable and makes it a potential anticancer agent.

Screening of HIV reverse transcriptase inhibitors is currently a strategy to search for anti-HIV drugs since HIV RT is a key enzyme in the HIV life cycle [28]. BSH inhibited HIV1 reverse transcriptase activity with an $\mathrm{IC}_{50}$ of $7.1 \mu \mathrm{M}$. Other lectins, such as L. flavidulus lectin $\left(\mathrm{IC}_{50}\right.$ of $\left.5.68 \mu \mathrm{M}\right)$ [17], $P$. adipose lectin $\left(\mathrm{IC}_{50}\right.$ of $\left.1.9 \mu \mathrm{M}\right)$ [26], and $H$. erinaceus $\left(\mathrm{IC}_{50}\right.$ of $31.7 \mu \mathrm{M}$ ) [27], also exhibited anti-HIV-1 RT activity, while R. lepida lectin [2] lacked it. Inhibitors targeted to the HIV-1 RT can be classified into two groups: nucleoside RT inhibitors (NRTIs) and nonnucleoside RT inhibitors (NNRTIs) [29]. $\mathrm{BSH}$, as a protein, belongs to NNRTIs group. The mechanism of inhibition is likely protein-protein interaction as in case of inhibition of HIV-1 reverse transcriptase by HIV-1 protease and cathelicidin [30]. Like lectins previously reported from mushrooms, BSH was devoid of antifungal activity [1]. Only a small number of the known constellations of plant lectins demonstrated antifungal activity [31].

\section{Conclusion}

In summary, a hemagglutinin with potent antiproliferative activity was isolated from thefruiting bodies of the hallucinogenic mushroom $B$. speciosus. It represents an addition to the existing list of mushroom hemagglutinating proteins since it is isolated from the family of rare mushrooms of Boletus genus and shows distinctive properties.

\section{Conflict of Interests}

The authors declare that they have no conflict of interests regarding the publication of this paper.

\section{Acknowledgments}

This work was financially supported by National Grants of China (31200070, 2010CB732202, and 2012BAD14B09), Beijing Higher Education Young Elite Teacher Project (YETP1714), and Beijing Innovative Grant of Modern Agricultural Technology System (PXM2013-014207-000096).

\section{References}

[1] H. Wang, T. B. Ng, and V. E. C. Ooi, "Lectins from mushrooms," Mycological Research, vol. 102, no. 8, pp. 897-906, 1998.

[2] G. Zhang, J. Sun, H. Wang, and T. B. Ng, "First isolation and characterization of a novel lectin with potent antitumor activity from a Russula mushroom," Phytomedicine, vol. 17, no. 10, pp. 775-781, 2010.

[3] T. B. Ng, "Peptides and proteins from fungi," Peptides, vol. 25, no. 6, pp. 1055-1073, 2004.

[4] M. A. W. P. de Jong, L. E. M. Vriend, B. Theelen et al., "C-type lectin Langerin is a $\beta$-glucan receptor on human Langerhans cells that recognizes opportunistic and pathogenic fungi," Molecular Immunology, vol. 47, no. 6, pp. 1216-1225, 2010.

[5] S. R. Dalton, R. L. Wiegert, and C. A. Casey, "An in vivo method for determination of endosomal distribution of both ligand and asialoglycoprotein receptor in rat liver," Comparative Hepatology, vol. 3, supplement 1, p. S38, 2004.

[6] M. Bovi, L. Cenci, M. Perduca et al., "BEL-trefoil: a novel lectin with antineoplastic properties in king bolete (Boletus edulis) mushrooms," Glycobiology, vol. 23, no. 5, pp. 578-592, 2013.

[7] F. Licastro, M. C. Morini, O. Kretz, G. Dirheimer, E. E. Creppy, and F. Stirpe, "Mitogenic activity and immunological properties of bolesatine, a lectin isolated from the mushroom Boletus satanas Lenz," International Journal of Biochemistry, vol. 25, no. 5, pp. 789-792, 1993.

[8] H. Wang and T. B. Ng, "A ribonuclease from the wild mushroom Boletus griseus," Applied Microbiology and Biotechnology, vol. 72, no. 5, pp. 912-916, 2006.

[9] M. Horibe, Y. Kobayashi, H. Dohra et al., "Toxic isolectins from the mushroom Boletus venenatus," Phytochemistry, vol. 71, no. 5-6, pp. 648-657, 2010.

[10] X. L. Mao, "Poisonous mushrooms and their toxins in China," Mycosystema, vol. 25, pp. 345-363, 2006.

[11] S. Zheng, C. Li, T. B. Ng, and H. X. Wang, "A lectin with mitogenic activity from the edible wild mushroom Boletus edulis," Process Biochemistry, vol. 42, no. 12, pp. 1620-1624, 2007.

[12] U. K. Laemmli and M. Favre, "Gel electrophoresis of proteins," Journal of Molecular Biology, vol. 80, pp. 575-599, 1973.

[13] X. Wu, J. Sun, G. Zhang, H. Wang, and T. B. Ng, "An antifungal defensin from Phaseolus vulgaris cv. 'Cloud Bean," Phytomedicine, vol. 18, no. 2-3, pp. 104-109, 2011.

[14] J. K. Zhao, Y. C. Zhao, S. H. Li, H. X. Wang, and T. B. Ng, "Isolation and characterization of a novel thermostable lectin from the wild edible mushroom Agaricus arvensis," Journal of Basic Microbiology, vol. 51, no. 3, pp. 304-311, 2011. 
[15] O. Kretz, E. E. Creppy, and G. Dirheimer, "Characterization of bolesatine, a toxic protein from the mushroom Boletus satanas Lenz and it's effects on kidney cells," Toxicology, vol. 66, no. 2, pp. 213-224, 1991.

[16] J. K. Zhao, H. X. Wang, and T. B. Ng, "Purification and characterization of a novel lectin from the toxic wild mushroom Inocybe umbrinella," Toxicon, vol. 53, no. 3, pp. 360-366, 2009.

[17] Y. Wu, H. Wang, and T. B. Ng, "Purification and characterization of a lectin with antiproliferative activity toward cancer cells from the dried fruit bodies of Lactarius flavidulus," Carbohydrate Research, vol. 346, no. 16, pp. 2576-2581, 2011.

[18] R. Eifler and P. Ziska, "The lectins from Agaricus edulis. Isolation and characterization," Experientia, vol. 36, no. 11, pp. 1285-1286, 1980.

[19] Q. She, T. Ng, and W. Liu, "A novel lectin with potent immunomodulatory activity isolated from both fruiting bodies and cultured mycelia of the edible mushroom Volvariella volvacea," Biochemical and Biophysical Research Communications, vol. 247, no. 1, pp. 106-111, 1998.

[20] Q. Liu, H. Wang, and T. B. Ng, "Isolation and characterization of a novel lectin from the wild mushroom Xerocomus spadiceus," Peptides, vol. 25, no. 1, pp. 7-10, 2004.

[21] H. Wang, J. Gao, and T. B. Ng, "A new lectin with highly potent antihepatoma and antisarcoma activities from the oyster mushroom Pleurotus ostreatus," Biochemical and Biophysical Research Communications, vol. 275, no. 3, pp. 810-816, 2000.

[22] C. H. Han, Q. H. Liu, T. B. Ng, and H. X. Wang, "A novel homodimeric lactose-binding lectin from the edible split gill medicinal mushroom Schizophyllum commune," Biochemical and Biophysical Research Communications, vol. 336, no. 1, pp. 252-257, 2005.

[23] H. Sychrova, M. Ticha, and J. Kocourek, "Studies on lectins. LIX. Isolation and properties of lectins from fruiting bodies of Xerocomus chrysenteron and Lactarius lignyotus," Canadian Journal of Biochemistry and Cell Biology, vol. 63, no. 7, pp. 700704, 1985.

[24] L. Yu, D. G. Fernig, J. A. Smith, J. D. Milton, and J. M. Rhodes, "Reversible inhibition of proliferation of epithelial cell lines by Agaricus bisporus (edible mushroom) lectin," Cancer Research, vol. 53, no. 18, pp. 4627-4632, 1993.

[25] H. X. Wang, T. B. Ng, W. K. Liu, V. E. C. Ooi, and S. T. Chang, "Isolation and characterization of two distinct lectins with antiproliferative activity from the cultured mycelium of the edible mushroom Tricholoma mongolicum," International Journal of Peptide and Protein Research, vol. 46, no. 6, pp. 508513, 1995.

[26] G. Q. Zhang, J. Sun, H. X. Wang, and T. B. Ng, "A novel lectin with antiproliferative activity from the medicinal mushroom Pholiota adiposa," Acta Biochimica Polonica, vol. 56, no. 3, pp. 415-421, 2009.

[27] Y. Li, G. Zhang, T. B. Ng, and H. Wang, "A novel lectin with antiproliferative and HIV-1 reverse transcriptase inhibitory activities from dried fruiting bodies of the monkey head mushroom hericium erinaceum," Journal of Biomedicine and Biotechnology, vol. 2010, Article ID 716515, 9 pages, 2010.

[28] W. M. Kati, K. A. Johnson, L. F. Jerva, and K. S. Anderson, "Mechanism and fidelity of HIV reverse transcriptase," The Journal of Biological Chemistry, vol. 267, no. 36, pp. 2598825997, 1992.

[29] G. Maga, D. Ubiali, R. Salvetti, M. Pregnolato, and S. Spadari, "Selective interaction of the human immunodeficiency virus type 1 reverse transcriptase nonnucleoside inhibitor efavirenz and its thio-substituted analog with different enzyme-substrate complexes," Antimicrobial Agents and Chemotherapy, vol. 44, no. 5, pp. 1186-1194, 2000.

[30] J. H. Wong, A. Legowska, K. Rolka et al., "Effects of cathelicidin and its fragments on three key enzymes of HIV-1," Peptides, vol. 32, no. 6, pp. 1117-1122, 2011.

[31] S. K. Lam, Q. F. Han, and T. B. Ng, "Isolation and characterization of a lectin with potentially exploitable activities from caper (Capparis spinosa) seeds," Bioscience Reports, vol. 29, no. 5, pp. 293-299, 2009. 

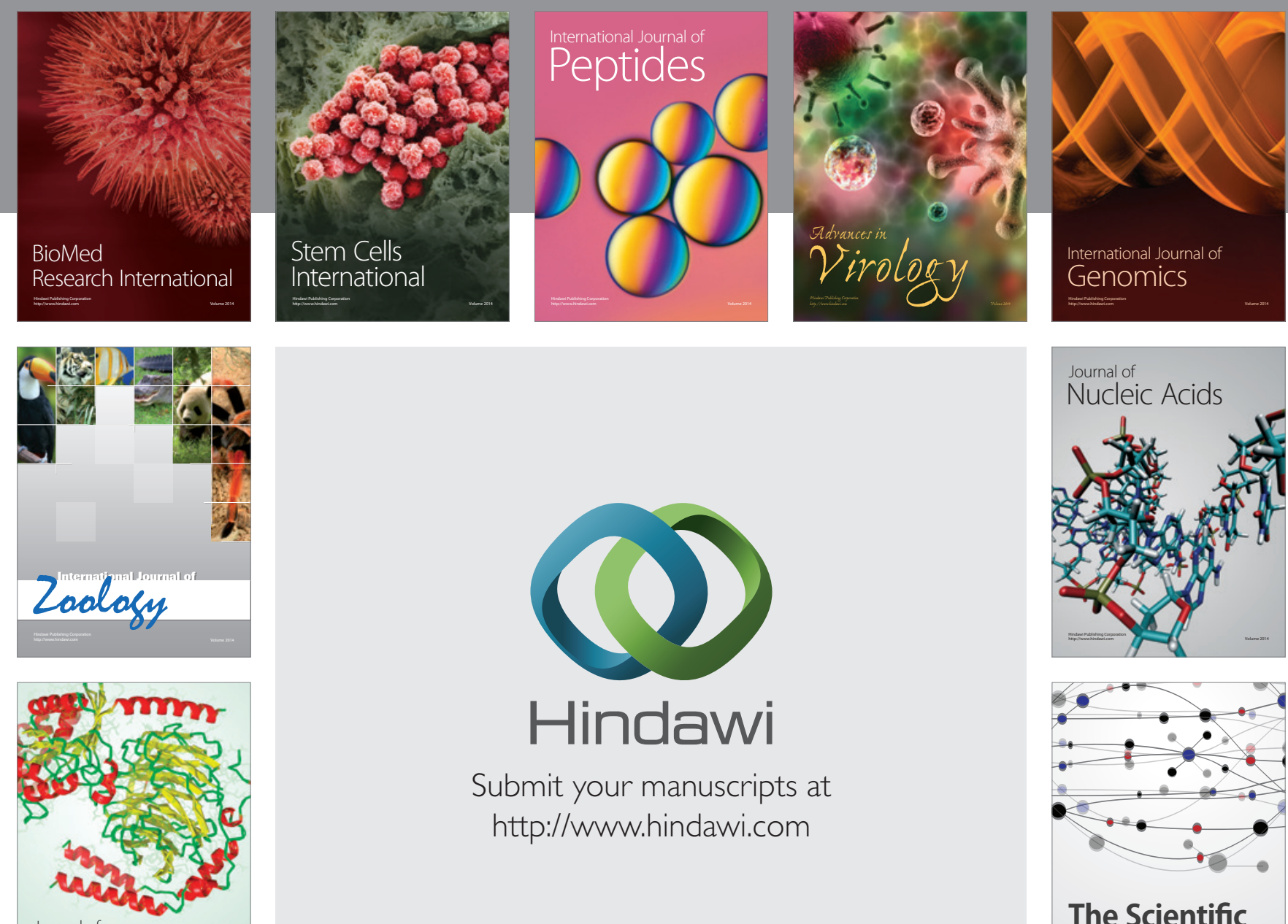

Submit your manuscripts at

http://www.hindawi.com

Journal of
Signal Transduction
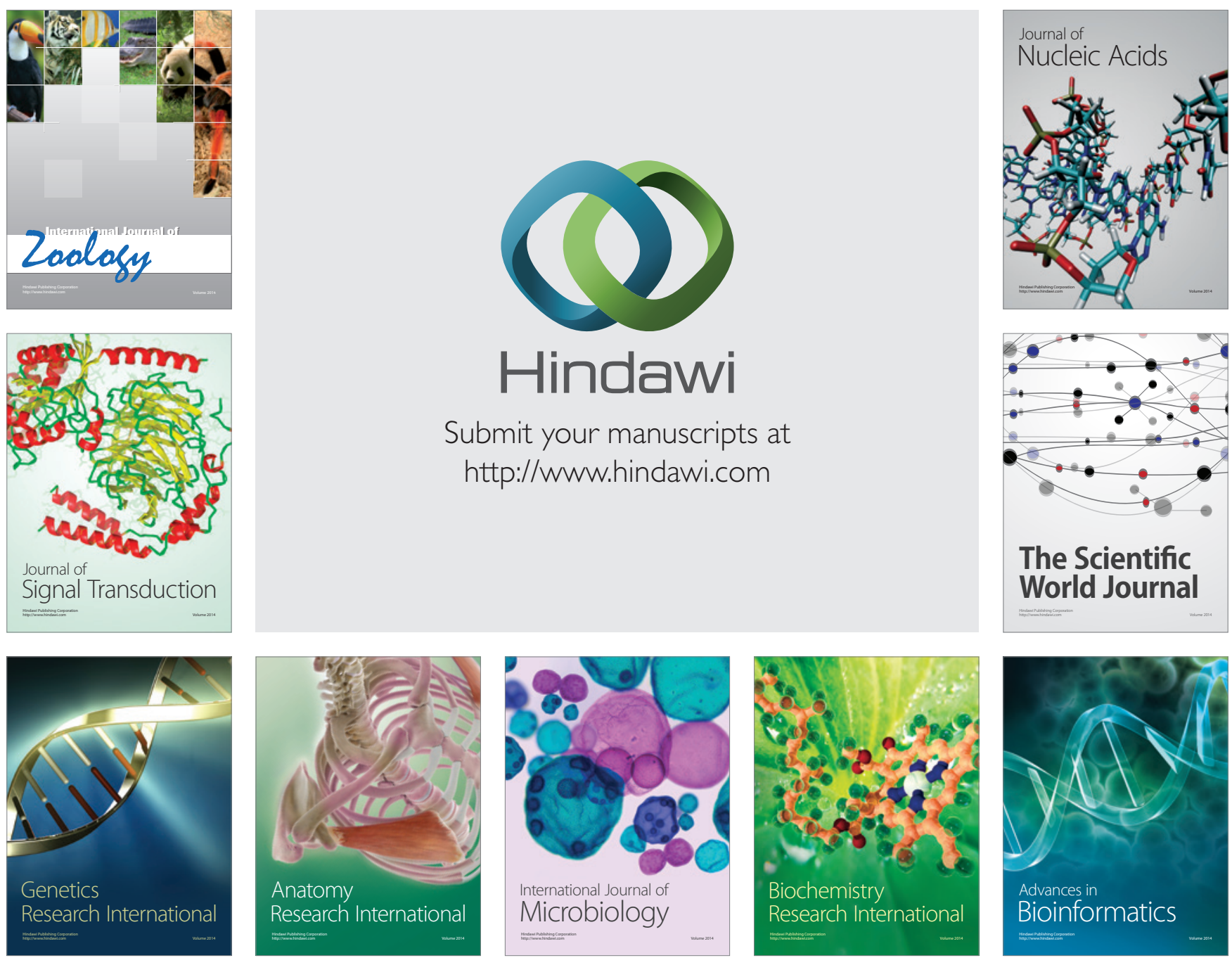

The Scientific World Journal
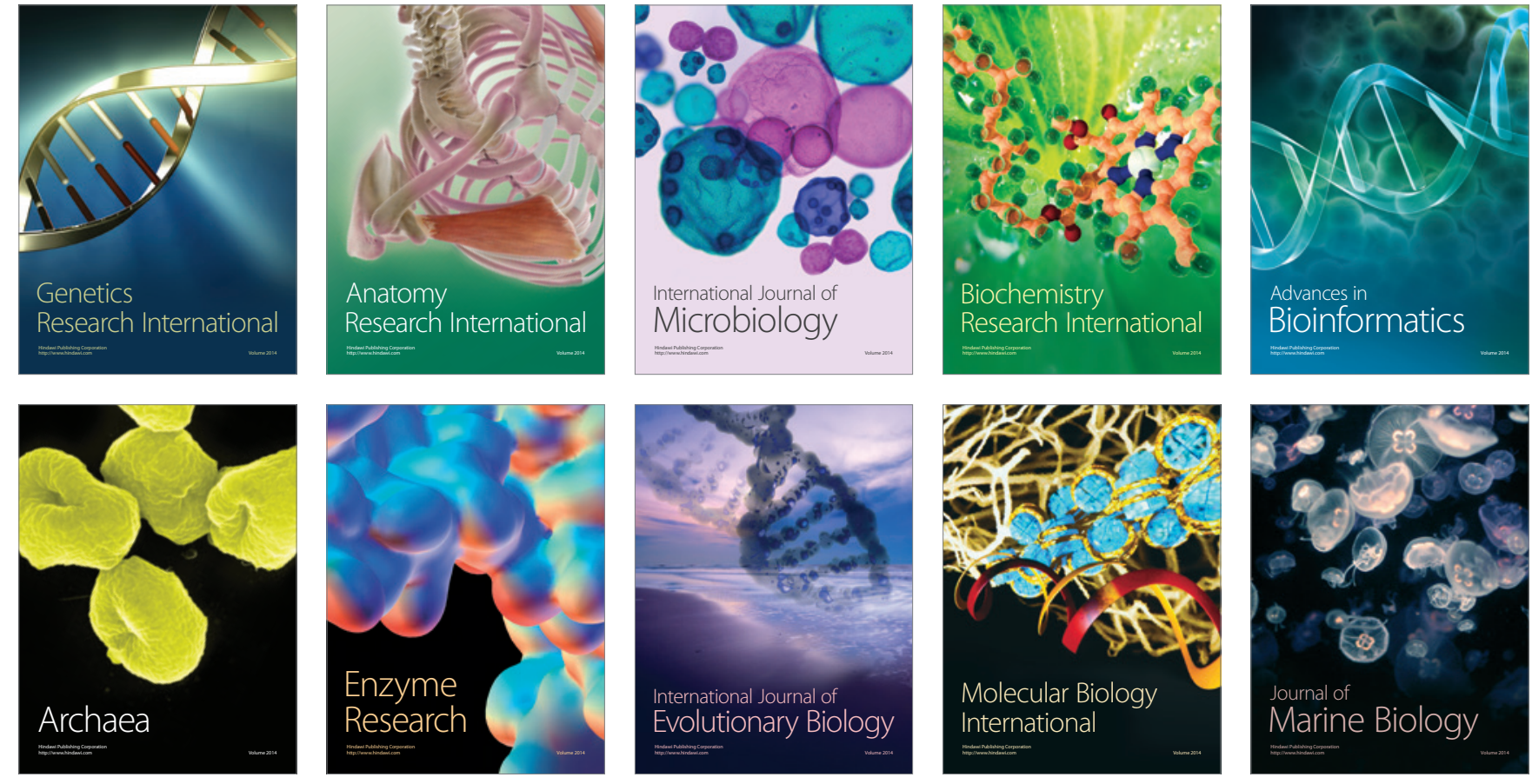